IIIII norden

\title{
Joint Nordic screening of emerging pollutants
}

Strategy and results
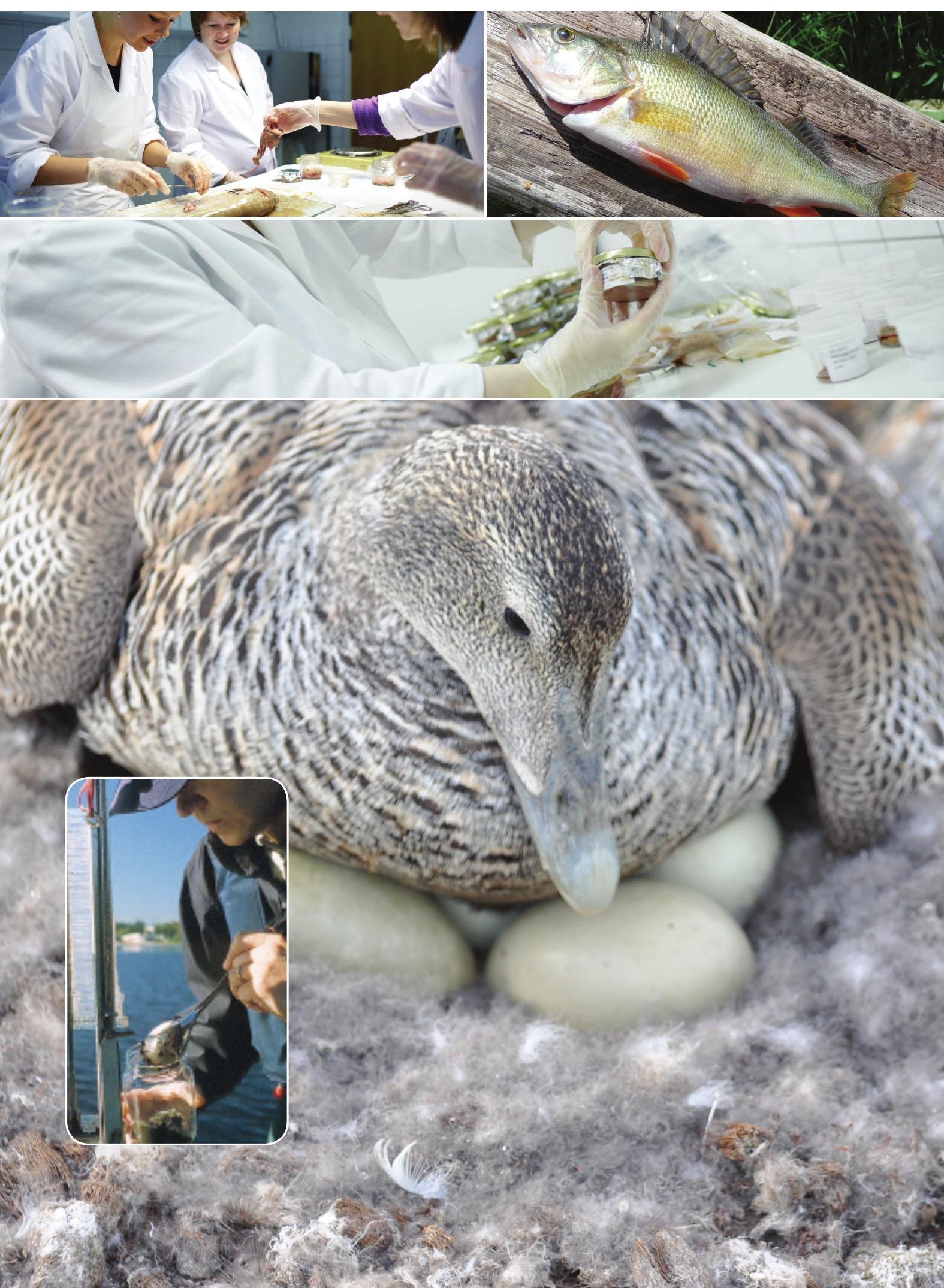
Joint Nordic screening of emerging pollutants

Strategy and results

ISBN 978-92-893-2815-9

http://dx.doi.org/10.6027/ANP2014-735

ANP 2014:735

(C) Nordic Council of Ministers, Copenhagen 2014

Layout: Jette Koefoed

For further information please contact Authors and Proofreaders:

Susanne Boutrup, DCE-Danish Centre for Environment and Energy,

DCE - Nationalt Center for Miljø og Energi, Aarhus University, Denmark (sub@dmu.dk)

Jaakko Mannio, Finnish Environment Institute (SYKE), Suomen ympäristökeskus,

Finland (jaakko.mannio@ymparisto.fi)

Maria Dam, Environment Agency, Umhvørvisstovan, the Faroe Islands (mariad@us.fo)

Tina Mønster, Ministry of Housing, Nature and Environment, Ineqarnermut,

Pinngortitamut Avatangiisinullu Naalakkersuisoqarfik, Greenland (tinm@nanoq.gl)

Bergpóra Hlízvist Skúladóttir, The Environment Agency of Iceland, Umhverfisstofnun,

Iceland (bergthoras@Umhverfisstofnun.is)

Britta Hedlund, Swedish Environmental Protection Agency, Naturvårdsverket,

Sweden (Britta.Hedlund@naturvardsverket.se)

Linda Linderholm, Swedish Environmental Protection Agency, Naturvårdsverket,

Sweden (linda.linderholm@naturvardsverket.se)

Eivind Farmen, Norwegian Environment Agency, Miljødirektoratet, Norway

(eivind.farmen@miljodir.no)

Bård Nordbø, Norwegian Environment Agency, Miljødirektoratet,

Norway (bard.nordbo@miljodir.no)

Photos front page: Top and background: Geir Wing Gabrielsen;

small photos left and middle: Environment Agency, Umhvørvisstovan, the Faroe Islands Top right and bottom left: Jaakko Mannio.

Copies: 200

Print: Rosendahls Schultz Grafisk

Printed in Denmark

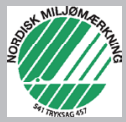

www.norden.org/en/publications

\section{Nordic co-operation}

Nordic co-operation is one of the world's most extensive forms of regional collaboration, involving Denmark, Finland, Iceland, Norway, Sweden, and the Faroe Islands, Greenland, and Åland.

Nordic co-operation has firm traditions in politics, the economy, and culture. It plays an important role in European and international collaboration, and aims at creating a strong Nordic community in a strong Europe.

Nordic co-operation seeks to safeguard Nordic and regional interests and principles in the global community. Common Nordic values help the region solidify its position as one of the world's most innovative and competitive.

\section{Nordic Council of Ministers}

Ved Stranden 18

DK 1061 Copenhagen K

Phone (+45) 33960400 


\section{Screening studies on emerging pollutants}

There are approximately 100.000 different chemical substances in use within the EU borders. We know that some of these are very hazardous and pose a risk to the environment. However, for the vast majority of substances, we simply don't have the knowledge to decide whether they pose a risk to the environment at the present time or maybe will do so in the future. To better understand such risks, one important first step is to measure these chemicals in the environment, to see whether they can be detected in water, soil or in living organisms. If the substances are persistent, bioaccumulative or toxic (PBT), they are regarded as hazardous. Substances with known hazardous properties are to a large extent regulated and included in national monitoring programs in the Nordic countries. The aim of screening for emerging pollutants is to collect knowledge that can be used in regulation of new hazardous chemicals.

The Nordic screening studies cover measurements of emerging pollutants in coordinated campaigns. Co-ordinated screening studies are handled by the Joint Nordic Screening Group which has representatives from each of the Nordic countries (see text box). The coordinated campaigns increase the scientific quality when samples from all the Nordic countries are included in one study. In addition, when all the analyses are performed by the same laboratory, the inter-laboratory uncertainty is eliminated. 


\section{Characteristics of emerging pollutants:}

- Available data on risk and concentration in the environment are scarce.

- Not included in national monitoring programs

- There are indications or proof that they are persistent and toxic and bioaccumulative

- Potential candidate for international measures (e.g. REACH, EU Directives and Stockholm convention)

- They are used in high volumes and released to the environment

The activities initiated by the screening group are financed and supported by the Nordic Council of Ministers through the Nordic Chemical Group (NKG) and the Marine Group (HAV) as well as the participating institutions.

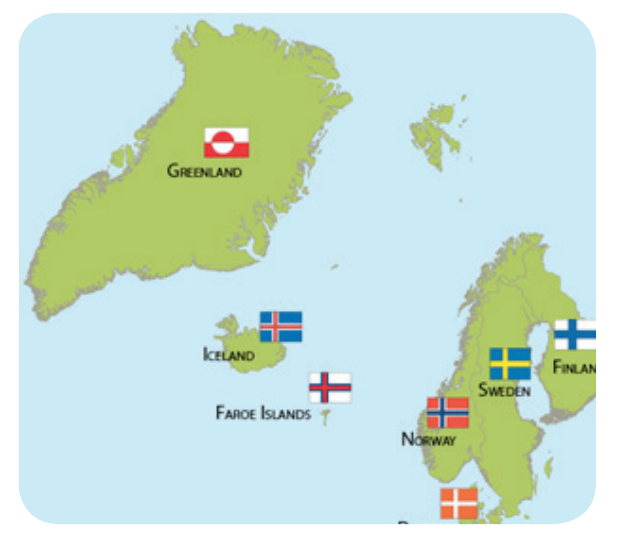

Institutions represented in the Joint Nordic Screening Group

DCE-Danish Centre for Environment and Energy, DCE - Nationalt Center for Miljø og Energi, Aarhus University, Denmark

Finnish Environment Institute (SYKE), Suomen ympäristökeskus, Finland

Environment Agency, Umhvørvisstovan, the Faroe Islands

Ministry of Housing, Nature and Environment, Ineqarnermut, Pinngortitamut Avatangiisinullu Naalakkersuisoqarfik, Greenland

The Environment Agency of Iceland, Umhverfisstofnun, Iceland Norwegian Environment Agency, Miljødirektoratet, Norway

Swedish Environmental Protection Agency, Naturvårdsverket, Sweden 
The activities in the Joint Nordic Screening Group can be divided into three areas: 1) Joint screening studies, 2) Sharing knowledge by organizing seminars and 3 ) literature studies. More information can be found at the webpage www.nordicScreening.org,

\section{Joint screening studies}

The aim of the joint Nordic screening studies is to obtain a snapshot of the occurrence of emerging pollutants in the environment. A Nordic cooperation on screening studies is an advantage for increased representativity of the results since it is possible to include a larger number of samples in a larger area than normally in national studies. In addition, it is cost effective and makes it easy to compare results with neighbouring countries.

\section{Selecting candidate pollutants for screening}

Selecting candidate pollutants for a screening study is a key task for the screening group. Based on conclusions from a workshop on the item in Lund 2012 (table 4) the screening group are now working with tree different approaches when selecting candidates for screening.

\section{Expert judgment approach:}

The group members will ask experts in each country for candidate substances. The substance selection is then discussed on a screening group meeting with focus on the following questions:

1. Does the substance pose a risk to the environment (PBT, endocrine disrupting potential)

2. Is the substance used in significant amounts and does the use pose a risk to the environment

3. Is the substance a potential candidate for, or already on international chemical lists (e.g. in the Stockholm Convention, REACH or the Water Framework Directive)

4. Do the properties of the substance indicate a risk for long range transport 
5. Do earlier screening studies indicate that the substance may pose an environmental risk

6. Is the substance proposed by more than one country

\section{Substances may also be removed from the list of candidates for screenings during the process. Criteria for deselecting substances are:}

1. The substance is already regulated through international conventions

2. The substance is already screened for in a similar area and existing data make it possible to conclude if there is an environmental risk

\section{Modeling approach:}

A contractor conducts a broad literature survey by using models like QSAR, exposure index or emission models. The survey must lead to a prioritized list of substances for screening.

\section{Analytical approach:}

A contractor looks for unknown compounds in environmental samples using techniques such as non-target analysis. Other possible analytical approaches include effect directed analysis (EDA). The objective to this method is to asses which chemicals, in an environmental sample, that are causing the biological effect.

\section{Use of results}

Results from the screening studies are used to determine whether emerging pollutants most likely pose a risk to the environment or not. Such data can be valuable input to the regulation of chemical, through international agreements such as Stockholm Convention and REACH. Furthermore, the results contribute to knowledge about emerging substances in the Nordic countries, and are also used for national measures like national priority lists, regulation of industry and national legislation. 


\section{Results obtained}

Table 1: Screening studies organised by the Joint Nordic Screening Group:

\begin{tabular}{|c|c|c|}
\hline Year & Substances chosen for screening & Report \\
\hline 2014 & Surfactants & Not published yet \\
\hline 2012 & Plasticisers and sweeteners & TemaNord 2013:505 \\
\hline 2011 & New Brominated Flame Retardants & TemaNord 2011:528 \\
\hline 2006 & Phenolic substances & TemaNord 2008:530 \\
\hline 2005 & Bronopol, resorcinol, triclosan, m-cresol & TemaNord 2007:585 \\
\hline 2004 & Siloxanes & TemaNord 2005:593 \\
\hline 2003 & Perfluorinated alkylated substances & TemaNord 2004:552 \\
\hline 2002 & Musk substances & TemaNord 2004:503 \\
\hline
\end{tabular}

\section{Plasticisers and sweeteners}

Plasticisers are additives that are used to increase the plasticity of a material, especially plastics. The plasticisers included in this study were long chained phthalates and adipates, and the sweeteners that were included were aspartame, cyclamate and sucralose.

- Samples were taken from municipal wastewater treatment plants and in sewage lines, but also from surface waters and from biota. Biota samples were collected both in assumed hot-spot areas and in background areas.

- $\quad$ For all sample types, the phthalates DEHP, DINP and DIDP were most frequently detected and found in the highest concentrations. The phthalates DBP and BBP were also found frequently but in lower concentrations. A general observation is that sites in direct vicinity of wastewater treatment plants had increased concentrations of plasticisers in sediments.

- Some of the substances were also found in biota, however the concentrations found in fish muscle were generally low and close to the limit of quantification (LOQ).

- The plasticisers included in the screening may be harmful to the environment. The fact that concentrations found in effluents and sediments were close to or exceeded predicted no effect concentration level in several cases, indicate that there is a need for follow-up studies to assess potential risks.

- The effluent water and some of the sludge samples from wastewater treatment plants were also analyzed for sweeteners. The results showed that there is a widespread occurrence of the sweeteners cyclamate and sucralose in effluent water in all the Nordic countries and that these substances are not profoundly accumulated in sludge. 
Table 2: Detection frequency of the individual plasticisers for the different sample matrices

\begin{tabular}{|c|c|c|c|c|c|c|}
\hline \multirow{4}{*}{$\begin{array}{l}\text { \% of sambles with } \\
\text { concentrations } \\
\text { above LOQ }\end{array}$} & & \multicolumn{2}{|c|}{ Effluent Sludge } & \multirow{2}{*}{$\begin{array}{c}\text { Sediment } \\
18\end{array}$} & \multirow{2}{*}{$\begin{array}{c}\text { Fish } \\
21\end{array}$} & \multirow{2}{*}{$\begin{array}{c}\text { Egg } \\
4\end{array}$} \\
\hline & Number of samples & 14 & 15 & & & \\
\hline & DBP & 79 & 100 & 84 & 48 & 50 \\
\hline & BBP & 100 & 100 & 63 & 0 & 0 \\
\hline 100 & DEHP & 93 & 100 & 84 & 81 & 0 \\
\hline 290 & L79P & 7 & 31 & 16 & 0 & 0 \\
\hline 180 & DOP & 64 & 88 & 26 & 0 & 0 \\
\hline$>70$ & DINP & 86 & 100 & 95 & 19 & 50 \\
\hline$>60$ & DIDP & 64 & 100 & 84 & 10 & 0 \\
\hline, 50 & DUP & 0 & 31 & 11 & 0 & 0 \\
\hline$>40$ & DEHA & 71 & 94 & 68 & 0 & 0 \\
\hline 130 & BOA & 14 & 25 & 0 & 0 & 0 \\
\hline 120 & DINA & 0 & 0 & 0 & 0 & 0 \\
\hline$s 10$ & DBEEA & 0 & 0 & 0 & 0 & 0 \\
\hline 10 & DEHZ & 0 & 0 & 0 & 0 & 0 \\
\hline
\end{tabular}

\section{Brominated Flame Retardants (BFR) in the Nordic Environment}

The Joint Nordic Screening Group has initiated a study investigating the occurrence of "new" brominated flame retardants (BFRs) in the Nordic environment. These "new" BFRs have in some instances replaced the more commonly known BFRs like PBDE. In this study 16 different BFRs were included. Flame retardants are used to reduce the flammability of polymeric materials and have been utilized in commercial materials for several decades.

- Samples analysed were in-door and out-door air, sediments and sludge from e.g sewage treatment plants and collecting wells in landfills and industrial sites and biota. The biota analysed were moss, freshwater and marine fish, marine mussels and seabird eggs.

- The overall results of this screening showed that emerging brominated flame retardants and Dechlorane plus were regularly found in all the sample matrices, indicating a widespread distribution in the Nordic environment. However, there were geographic differences and differences in occurrence among substances and groups of substances.

- A preliminary risk assessment was done with basis on the identified levels of "new" BFRs in the various samples types. The lack of information on physicochemical properties and toxicity data in particular, hindered the completion of a satisfactory preliminary risk assessment 
Table 3: Detection frequency (\%) of the individual brominated flame retardants for the different sample matrices. Higher detection frequency is marked with a darker colour

\begin{tabular}{|c|c|c|c|c|}
\hline Matrix & Air & Sediment & Sludge & Biota \\
\hline \multirow[t]{2}{*}{ Number of samples } & 12 & 15 & 16 & 21 \\
\hline & $\%$ & $\%$ & $\%$ & $\%$ \\
\hline \multicolumn{5}{|l|}{ Phenolic BFRs } \\
\hline 24DBP & 58 & 78 & 8 & 39 \\
\hline 246TBP & 50 & 92 & 23 & 91 \\
\hline PBP & 8 & 8 & 15 & 17 \\
\hline TBBPA & 17 & 8 & 15 & 0 \\
\hline \multicolumn{5}{|l|}{ BFR esters \& ethers } \\
\hline ATE & 33 & 8 & 31 & 4 \\
\hline DPTE & 67 & 8 & 31 & 17 \\
\hline BTBPE & 92 & 50 & 100 & 91 \\
\hline BATE & 25 & 0 & 31 & 4 \\
\hline TBA & 100 & 100 & 100 & 100 \\
\hline BEHTBP & 75 & 17 & 100 & 70 \\
\hline EHTeBB & 92 & 25 & 77 & 57 \\
\hline \multicolumn{5}{|l|}{ Others flame retardants } \\
\hline DP & 75 & 100 & 100 & 52 \\
\hline HBB & 92 & 50 & 31 & 100 \\
\hline PBT & 92 & 92 & 100 & 100 \\
\hline PBEB & 67 & 58 & 69 & 43 \\
\hline DBDPE & 100 & 50 & 100 & 70 \\
\hline TBECH, sum & 92 & 50 & 46 & 81 \\
\hline \multicolumn{5}{|l|}{ Reference BFR } \\
\hline BDE-28 & 100 & 94 & 75 & 100 \\
\hline BDE-47 & 100 & 100 & 83 & 100 \\
\hline BDE-71/49 & 50 & 89 & 83 & 100 \\
\hline BDE-66 & 33 & 44 & 25 & 70 \\
\hline BDE-77 & 17 & 6 & 0 & 10 \\
\hline BDE-99 & 100 & 100 & 75 & 100 \\
\hline BDE-100 & 67 & 100 & 75 & 100 \\
\hline BDE-85 & 33 & 22 & 17 & 25 \\
\hline BDE-119 & 0 & 0 & 0 & 35 \\
\hline BDE-138 & 33 & 22 & 25 & 5 \\
\hline BDE-153 & 50 & 50 & 75 & 80 \\
\hline BDE-154 & 50 & 67 & 75 & 100 \\
\hline BDE-183 & 67 & 50 & 75 & 40 \\
\hline BDE-196 & 33 & 17 & 50 & 10 \\
\hline BDE-206 & 50 & 39 & 83 & 30 \\
\hline BDE-209 & 100 & 78 & 92 & 95 \\
\hline
\end{tabular}




\section{Sharing knowledge and experience}

In the Nordic countries there is a tradition for monitoring or investigating spatial and temporal trends of pollutants. Sharing of knowledge and experience from these activities contributes to optimising the output of the efforts in the individual countries.

Since 2001, the Joint Nordic Screening Group has arranged six seminars for sharing knowledge and experience (see table 4). Researchers as well as administrators in the Nordic countries have taken part in the seminars. Some of the questions that have been discussed on the seminars are "How do we select the most relevant substances for screening studies?", "How are the results from screening studies used in the administrations?" and "How do we handle the challenges and pitfalls in screening studies?"

\begin{tabular}{|c|c|c|}
\hline year & topic & location \\
\hline 2014, April 8-9 & Non target screening & Ystad, Sweden \\
\hline \multirow[t]{2}{*}{ 2012, May 7-8 } & Today's chemical solution & \\
\hline & - problems of tomorrow? & Lund, Sweden \\
\hline 2010, Oct. 11-12 & Nordic seminar on environmental screening & Malmö, Sweden \\
\hline \multirow[t]{2}{*}{ 2008, Nov. 5-6 } & Workshop on Pharmaceuticals and Personal Care & \\
\hline & Products (PPCPs) in the Nordic Environment & Oslo, Norway \\
\hline 2007, Sept. 24-25 & $\begin{array}{l}\text { Workshop on environmental screening } \\
\text { and risk assessment }\end{array}$ & Landskrona, Sweden \\
\hline \multirow[t]{2}{*}{ 2001, June 6-8 } & Workshop on Monitoring the Environmental & \\
\hline & Fate of Chemicals & Sigtuna, Sweden \\
\hline
\end{tabular}




\section{Literature studies}

The third task handled by the Joint Nordic Screening Group is organising literature studies compiling information or data on a certain subject across the Nordic countries. This work has been funded by the Nordic Council of Ministers, but it is also partly funded by participating national institutions, depending on resources and demand.

The literature studies construct an overview that can form the basis for selection of the most relevant substances for screening. One example is the literature study on plasticisers and sweeteners from 2010. This study lists data on consumption, toxicity and physicochemical properties of the individual substances. Based on this study, the substances for the screening study of plasticisers and sweeteners were selected TemaNord 2013:505.

Pharmaceuticals and personal care products (PPCP) have been in focus in each of the Nordic countries in the recent years. This has resulted in a number of different studies. Data from these studies are compiled in the literature study on PPCP. The report gives the administrators a valuable instrument in the assessment of their own data and in the assessment of the need for investigating new PPCPs.

Table 5: Literature studies arranged by Joint Screening Group or the participating national institutions.

\begin{tabular}{lll}
\hline Year & Topic & Report \\
\hline 2013 & Literature Survey of Surfactants in the Nordic Countries & Link to report \\
\hline 2011 & PPCP monitoring in the Nordic Countries - Status Report & Link to report \\
2010 & Plasticisers and sweeteners in the Nordic countries & Link to report \\
2007 & Current State of Knowledge and Monitoring requirements & \\
& Emerging 'new' Brominated flame retardants in flame & \\
& retarded products and the environment & Link to report \\
\hline 2002 & Nordic Pesticide Monitoring Programmes & Link to report \\
\hline
\end{tabular}

Links to national reports on emerging pollutants

Danish reports http://dce.au.dk/udgivelser/

Swedish reports http://dvss.ivl.se/registersida.aspx

Finnish reports http://www.syke.fi/en-US/Research_Development/Consumption_and_ production_and_sustainable_use_of_natural_resources/Publications

Norwegian reports http://www.miljodirektoratet.no/no/Publikasjoner/Statlig_miljoover vakning/Kartlegging_av_nye_miljogifter/ 


\section{Nordic Council of Ministers}

Ved Stranden 18

DK-1061 Copenhagen K

www.norden.org

\section{Joint Nordic screening of emerging pollutants}

Strategy and results

This brochure highlights the work conducted by the Joint Nordic screening group. The activities in the Joint Nordic Screening Group can be divided into three areas: 1 ) Joint screening studies, 2) Sharing knowledge by organizing seminars and 3 ) literature studies.

The aim of the joint Nordic screening studies is to obtain a snapshot of the occurrence of emerging pollutants in the environment. A Nordic cooperation on screening studies is an advantage for increased representativity of the results since it is possible to include a larger number of samples in a larger area than normally in national studies. In addition, it is cost effective and makes it easy to compare results with neighbouring countries.

The group has its own webpage, from where the reports can be downloaded. 